\title{
Design of Curriculum Matrix for Robotics Education Derived from Bloom's Taxonomy and Educational Curriculum of 2013
}

\author{
Eko Henfri Binugroho ${ }^{1}$, Endah Suryawati Ningrum ${ }^{1}$, Dwi Kurnia Basuki ${ }^{2}$, \\ and Adnan Rachmat Anom Besari ${ }^{2}$
}

\begin{abstract}
Even though robotics have gaining an attention from students of every education all evel since elementary school up to higher education, their impact in student's education itself is still relatively small. Most of the robotics competitions in Indonesia are still focus on the result but not in the process. This paper presents an educational matrix of curriculum based on robotics which focused on the process and learning outcomes of the education. The proposed Curriculum Matrix is derived from Bloom's Taxonomy which synchronized with the Educational Curriculum of 2013 from the Indonesian Ministry of Education and Culture.Hereafter, the activities of education are designed based the available robotics module together with the designed Curriculum Matrix. By using the Curriculum Matrix, the proportion of education activities can be evaluated to achieve the learning outcomes for the specified educational level more easily.
\end{abstract}

Keywords-robotics, education, learning activities, learning outcomes, education level

\section{INTRODUCTION}

$\mathrm{R}$ obotics has attracted the high interest of teachers and researchers as a valuable tool to develop cognitive and social skills for students from pre-school to high school and to support learning in science, mathematics, technology, informatics and other school subjects or interdisciplinary learning activitiesduring the last decade [1,2]. The antusiasm also came from the students, which isindicated by an increasing number of participants in many robotics competitions have held in Indonesia year by year.Many studies have been conducted in theinvestigation in the field of educational roboticsand identification of the new challenges and trends focusing on the use of robotic technologies as a tool that will support creativity and other $21^{\text {st }}$ century learning skills.

Robotics in education is seen as an interdisciplinary, project-based learning activity drawing mostly on math, science, and technology and offering major new benefits in education at all levels [3].Practical demonstrations and hands-on experience encourage students and increase motivation. Besides learning engineering concepts, students performing robotic exercises develop valuable skills like creativity, teamwork,designing and problem solving. The benefits of using robots in education have been widely reported, e.g. [4-6]. It has much potential to offer in education, however, the benefits in learning are not guaranteed for students just by the simple introduction of robotics in the classroom, as there are several factors that can determine the outcome; technology alone cannot affect minds. Robots are not the end point for improving learning; the real fundamental issue is not the robot itself; but, the curriculum [7].

${ }^{1}$ Eko Henfri Binugroho and Endah Suryawati Ningrum are with Department of Mechanical and Energy Engineering, Electronic Engineering Polytechnic Institute of Surabaya, 60111, Indonesia. Email: sragen@eepis-its.edu and endah@eepis-its.edu.

${ }^{2}$ Dwi Kurnia Basuki and Adnan Rachmat Anom Besari are with Department of Informatics and Computer Engineering, Electronic Engineering Polytechnic Institute of Surabaya, 60111, Indonesia. Email: dwiki@eepis-its.edu and anom@eepis-its.edu.
Robots are just another tool, and it is the curriculum that will determine the learning result and the alignment of technology with sound theories of learning.

An appropriate educational philosophy, namely constructivism and constructionism, the curriculum and the learningenvironment are some of the important elements that can lead robotics innovation tosuccess [8]. The emphasis should be shifted from the technology towards partnership with learning theories putting the emphasis on the curriculum than on the technology. Thecurriculum is the keystone in educational robotics and it is necessary to incorporate the basicprinciples of learning and to set qualitative and quantitative performance metrics forexpected outcomes and for validation of the curriculum. Technology education is a program designed to help students develop an understanding and competence in designing, producing, and using technological products and systems, and in assessing the appropriateness of technological actions [9]. Indeed, students have an opportunity to learn about the processes and knowledge related to technology that are needed to solve problems and extend human capabilities through technology education.

This paper proposes a curriculum matrix that emphasize the student's learning process to achieve the learning outcomes by using a robotics as the learning tools. By using the proposed curriculum matrix, the proportion of learning activities can be evaluated to achieve the learning outcomes for the specified educational level more easily. To synchronize with the formal education activities achieved in school, the study uses the Educational Curriculum of 2013 from the Indonesian Ministry of Education and Culture as the reference.

\section{METHOD}

The creation and widespread acceptance of such a curriculum framework could help to bring a greater degree of solidarity to a fragmented assortment of approaches to the delivery of technology education courses currently practiced in high schools [8]. The 
method used in this study is composed as the following steps:

1) Determine the learning outcomes

2) Determine the learning subjects

3) Design the curriculum matrix

4) Design the handout framework

Three categories of learning can be catagorized into KSA (Knowledge, Skills, and Attitude). This taxonomy of learning behaviors can be thought of as "the goals of the learning process." That is, after a learning episode, the learner should have acquired new skills, knowledge, and/or attitudes. Bloom's taxonomy is easily understood and is probably the most widely applied one in use today.In this study, Bloom's Taxonomy is used as the main reference to determine the learning outcomes for the learning activities. Taxonomy simply means classification, so the Bloom's Taxonomy of learning objectives is an attempt to classify forms and levels of learning [10]. It identifies three domains of learning and each of which is organized as a series of levels or prerequisites. Categories were formulated for cognitive (thinking and problem-solving skills), affective (attitudes, value systems), and psychomotor domains. It is suggested that one cannot effectively address higher levels until those below them have been covered. As well as providing a basic sequential model for dealing with topics in the curriculum, it also suggests a way of categorizing levels of learning, in terms of the expected ceiling for a given programme [11].

For over 50 years, Bloom's Taxonomy has strongly influence teaching and its assessment throughout the world [12] and commonly used in mathematics education. Numerous studies have used Bloom's Taxonomy as the standard for judging whether tested items are Lower-Order-Thinking (LOT) or HigherOrder-Thinking (HOT). The thinking skills in BT considered LOT include knowledge and understanding, while the thinking skills of analysis, synthesis and evaluation are considered HOT [13].

\section{A. Cognitive Domain}

The cognitive domain involves knowledge and the development of intellectual skills. This includes the recall or recognition of specific facts, procedural patterns, and concepts that serve in the development of intellectual abilities and skills. Lorin Anderson, a former student of Bloom, revisited the cognitive domain in the learning taxonomy in the mid-nineties and made some changes, with perhaps the two most prominent ones being, 1) changing the names in the six categories from noun to verb forms, and 2) slightly rearranging themby swap the position of creating and evaluating catagories [14]. This new taxonomy reflects a more active form of thinking, as can be seen in Table 1 .

\section{B. Affective Domain}

The affective domain includes the manner in which we deal with things emotionally, such as feelings, values, appreciation, enthusiasms, motivations, and attitudes [15]. The five major categories as shown in Table 2 are listed from the simplest behavior to the most complex.

\section{PsychomotorDomain}

The psychomotor domain includes physical movement, coordination, and use of the motor-skill areas.
Development of these skills requires practice and is measured in terms of speed, precision, distance, procedures, or techniques in execution [16]. The seven major categories as shown in Table 3 are listed from the simplest behavior to the most complex behavior.

A technology education curriculum with an emphasis on engineering design should foster teamwork and interpersonal skills. It should also focus on the ethical responsibility of the designer to his or her fellow human beings. Inline with the purposes to prepare students with skills required when they become adults, this study also refers to Equipped for the Future (EFF) Content Standards. The Standards have been identified through research on what adults need to do to meet the broad areas of responsibility that define these central adult roles. It defines four catagories of skills and then defined into 16 items for the future standards as the core knowledge and skills adults need to effectively carry out their roles [17]. Those standards are:

1. Communication Skills

- $\quad$ Read With Understanding

- Convey Ideas in Writing

- Speak So Others Can Understand

- Listen Actively

- Observe Critically

2. Interpersonal Skills

- Cooperate With Others

- Guide Others

- Advocate and Influence

- Resolve Conflict and Negotiate

3. Decision-Making Skills

- Solve Problems and Make Decisions

- Plan

- Use Math to Solve Problems and Communicate

4. Lifelong Learning Skills

- Take Responsibility for Learning

- Learn Through Research

- Reflect and Evaluate

- Use Information and Communications Technology

The Educational Curriculum 2013 from the National Ministry of Education and Culture mentions the scope of competency as levels of knowledge from each level of formal education like shown in Figure 1. It divides the scope of competency in to the knowledge dimensions as Factual Knowledge, Conceptual Knowledge, Procedural Knowledge, Meta-cognitive Knowledge. The Bloom's Revised Taxonomy [18] describes those knowledge dimensions as follows:

\section{Factual Knowledge}

Basic elements used to communicate, understand, organize a subject: terminology, scientific terms, labels, vocabulary, jargon, symbols or representations; and specific details such as knowledge of events, people, dates, sources of information.

\section{Conceptual Knowledge}

Knowledge of classifications and categories, principles, theories, models or structures of a subject.

\section{Procedural Knowledge.}

Knowing how to do something: performing skills, algorithms, techniques or methods.

4. Metacognitive Knowledge 
The process or strategy of learning and thinking; an awareness of one's own cognition, and the ability to control, monitor, and regulate one's own cognitive process.

From the Figure 1 can be concluded that, the higher the education level, the higher level of knowledge should be achieved.

\section{RESULT AND DISCUSSION}

In order to synchronized the curriculum with the outcomes obtained from the formal education, the outcomes of knowledge and skill of the students are leveled based on their level of education. In this paper we devided them into three levels of knowledge and skill; basic, intermediate, and advance; which is shown in Table 4. These level of outcomes can be described as follows:

A. Basic knowledge and skill including:

1. Know what the basic function is,

2. Know how the stuff works with the minimum level of understanding,

3. Know how to use the stuff with the minimum level of understanding,

4. Know how to apply the stuff with the minimum level of understanding.

B. Intermediate knowledge and skill including:

1. Understand what the function is,

2. Understand how the stuff works,

3. Understand how to use the stuff,

4. Understand how to apply the stuff,

5. Able to analyze how the stuffs works with the intermediate level of understanding.

6. Able to evaluate the stuff with the intermediate level of understanding

C. Advance knowledge and skill including:

1. Understand the function clearly,

2. Understand how the stuff works clearly,

3. Understand how to apply the stuff clearly,

4. Able to analyze how the the stuffs works clearly,

5. Able to evaluate the stuff clearly,

6. Able to modify the stuff,

7. Able to create a new stuff prior to the obtained knowledge and skill.

To make a better picture for the relationship between learning outcomes and courses/subjects in the curriculum, we use a Curriculum Matrix. It assigns the level of activities to obtain the outcomes according to the given courses. The activity in each subject/course prior to the learning outcome are divided into four categories, as:

I = Introduction;

The subject is introduced to the students, so the student know about the material. The student understanding is evaluated by using observation and direct question and answer prosedure.

$\mathrm{C}=$ Comprehension;

The subject is explained in more detail, so the students understand about the material. The student's comprehension thus evaluated by using observation and paper test.

$\mathrm{P}=$ Practice:;
The students do some activities to use the toll or material in the subject directly to master it. The ecaluation thus taken by the observing the process and by evaluating the result of the student's work.

A = Assessment;

The assignment are given to the student. Thus studentsare obligated to do some action to complete the assignment to measure their understanding, knowledge, skills or attitudes.

In the curriculum Matrix, EFF Content Standards are adopted in Affective Domain learning outcomes from the Bloom's Taxonomy. Some of it also used in the Cognitive Domain mixed with some criteria from ABET Engineering Criteria [19]. Catagories from those standards combined with Bloom's Taxonomy to determine the better picture in determining learning outcomes in the Curriculum Matrix. Table 5 shows the designed Curriculum Matrix which is focused on the learning outcomes in the Cognitive Domain derived from the revised Bloom's Taxonomy. Table 6 shows the designed Curriculum Matrix which is focused on the learning outcomes in the Affective Domain. Table 7 shows the Curriculum Matrix which is focused in the Psychomotor Domain. In each Curriculum Matrix, the levels of outcomes are listed from the simplest to the most complex. It means that the step of the learning should start from the simplest outcome first. The proportion of each type of activity (course category) in each domain of learning outcomes can be seen from Figure 2.

To achieve the learning outcomes defined in the Curriculum Matrix, this paper uses three methods that been proposed to achieve outcomes in ABET Engineering Criteria [20]. Those methods are; (1) General Instructional Methods, (2) Problem-Based Learning, and (3) Cooperative Learning. The content of each method then defined to be suitable with the subject/course mentioned in the Curriculum Matrix.

\section{A. General Instructional Methods}

An effective approach to achieving any desired learning outcome is by showing the students the course learning objectives that address that outcome. It can be given before the course begin. The more explicitly students know what they are expected to doand the more practice they get in doing it, the greater the likelihoodthat they will acquire the desired skills [21, 22].This method can be implemented in all subject/courses in the Curriculum Matrix. For Introduction and Comprehension courses, a handout or instructional module should be given to the student. Thus the instructor should explain the content of the tutorial (hand out). The instruction may take the form of mini-lectures, supplementary readings, or best of all, interactivemultimedia tutorials. Another effective technique is to provide a demostration from the material mentioned in the handout. Student may give a question to the intructor about the material in the handout, or other else related to the course. In the other hand, instructor may also randomly pick-up students and then give them a question directly to measure the student understanding about the subject.

Practice and Assessment course can be designed in to guided experiment or more open-ended experiments. In an open-ended experiment, an objective (determine a 
physical property, establish an empirical correlation, validate or refute a theoretical prediction) is given to the student. A handout is provided as base line guidance for the student such as in how to conduct the experiment safely, how to use the experimental tools, etc. This is up to the students who will design the experimentation in detail, such as experimental conditions, specify how many runs to carry out at each condition and the data to be collected, plan the data analysis to be carried out, etc. After that they should run the experiment, collect the data, perform the data analysis and in perpetration, draw conclusions, and prepare and submit the report.

The framework of the handout module used to conduct the courses is designed as follows:

- Course Description

- Learning Objectives

- Learning Outcomes

- Learning Methods

- Mechanism of Learning

- Description of Activity

- Materials and Tools

- Allocation of Time

- Evaluation Method (based on Rubric Scoring)

$\circ \quad$ Evaluation of the learning process

- Evaluation of learning outcomes

\section{B. Problem-Based Learning}

Robotics can be use as one of the effective method to implement the instructional method known as ProblemBased Learning (PBL). Once PBL has been adopted in a course, very little additional work must be done to address all of Outcomes. Focus problems may be chosen to involve any experimental or analytical technique, tool, technical or interpersonal skill, or professional or contemporary societal issue that the instructor chooses to address. Robotics Competition is the most suited test case to implement PBL from the courses mentioned in Table 4. The entire courses and individual topics within courses are introduced with complex open-ended focus problems whose solutions will require the knowledge and skills set forth in the course learning objectives [23, 24]. There are many solutions can be deployed to solve the problem. This case is used to test the creativity of the students in finding the solution from the given problem. They may looking to the problem from many different point of views.

In the robotics competition, the problem is given in a form of a competition rule, in which the students should solve the given problem using the robot. The students which are working in a team will carry out the following steps:

1. Attempt to write a clear problem definition statement (derived from the competition's rule).

2. Hypothesize ways to obtain a solution (according to the different point of views).

3. Identify (a) what they know, (b) what they need to know (both information and methods), and (c) what they need to do. These lists are regularly updated as the students proceed through the solution process.

4. Prioritize learning needs, set learning goals and objectives, and allocate resources in the team.

5. Carry out the necessary research and analysis and generate possible solutions by firstly seeing if the problem can be solved with currently known information,examine their viability and efectiveness, and then choose the most appropriate one, and finally defend the choice.

6. Reflect critically on the new knowledge, the problem solution, and the effectiveness of the solution process used.

In each team, there is a mentor who will serves as a resource in all stages of this process, but does not provide formal instruction until the students have generated a need for it in the context of theproblem. Mentor just givesguidance to the team, not a direct path to follow. Any teaching method may be used to provide the instruction, ranging from lecturing to full-scale cooperative learning. Relative to students taught conventionally, students taught using PBL acquire greater mastery of problem-solving, interpersonal, and lifelong learning skills and are more likely to adopt a deep (as opposed to surface or rote) approach to learning [24, 25].

\section{Cooperative Learning}

During the Practice and Assessment courses, students are divided into teams. It means that Cooperative Learning (CL) method is suitable to be implemented in those courses. This method also can foster the "Teamwork course" as well. CLis an instruction that involves students working in teams to accomplish a common goal, under conditions that include the following elements [26]:

1. Positive interdependence.Team members are obliged to rely on one another to achieve the goal.

2. Individual accountability. All students in a group are held accountable for doing their share of the work and for mastery of all of the material to be learned.

3. Face-to-face promotive interaction. Although some of the group work may be parceled out and done individually, some must be done interactively, with group members providing one another with feedback, challenging one another's conclusions and reasoning, and perhaps most importantly, teaching and encouraging one another.

4. Appropriate use of collaborative skills. Students are encouraged and helped to develop and practice skills in communication, leadership, decision-making, conflict management, and other important aspects of effective teamwork.

5. Regular self-assessment of group functioning. Team members periodically assess what they are doing well as a team and what they need to work on, and they identify changes they will make to function more effectively in the future.

\section{CONCLUSION}

Curriculum is a very important thing in a learning process. The first required step in designing a curriculum is determining the learning outcomes. Learning outcomes can refer to one of the standards referenced in accordance to the type of learning and the learning objectives. Bloom's Taxonomy which is already widely used in many academic activities has been adopted in this paper in developing the educational robotics curriculum. The depth of the robotics courses and subjects in the curriculum has been adjusted in order to be synchronized with the formal education of the 
students, based on the Curriculum 2013 criteria. To make a clearer picture, Curriculum Matrix has been developed to easily map the learning outcomes and learning activities. By using it, teachers can easily develop the teaching material based on the learning outcomes and course type inside the matrix. The students also can easily imagine what kind of competency would be obtained after taking the courses. General Instructional

Methods, PBL, and CL are among the learning methods that can be adopted in the proposed curriculum.

\section{ACKNOWLEDGEMENT}

This research is conducted by EEPIS Robotics Research Center (ER2C) in Electronic Engineering Polytechnic Institute of Surabaya (EEPIS). This works was supported by EEPIS Center for Research and Community Service.

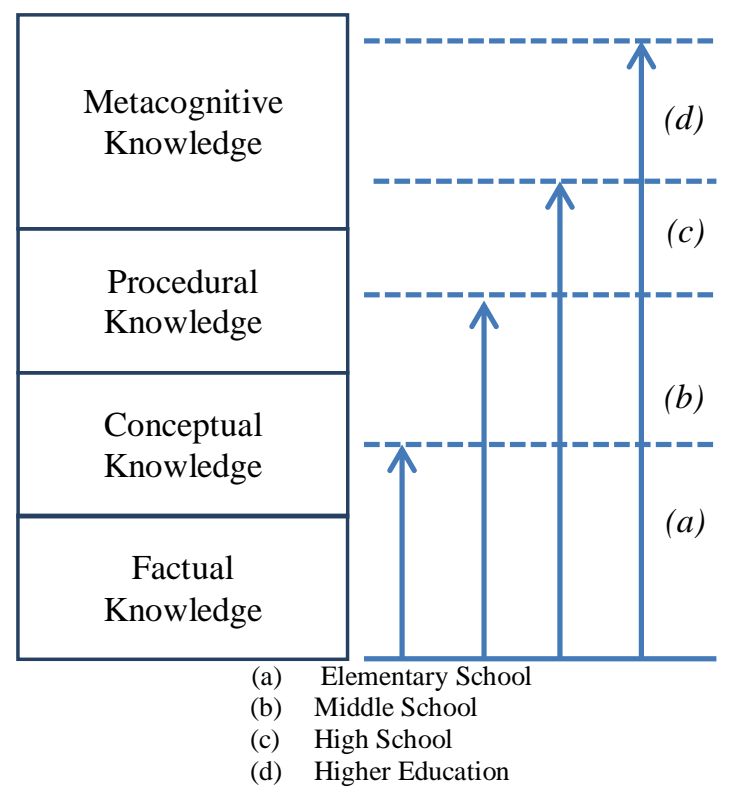

Figure. 1. Knowledge dimensions obtained in each level of education

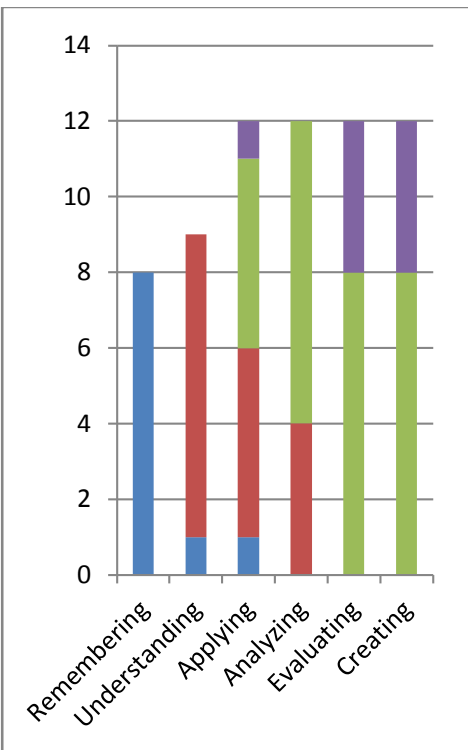

(a)

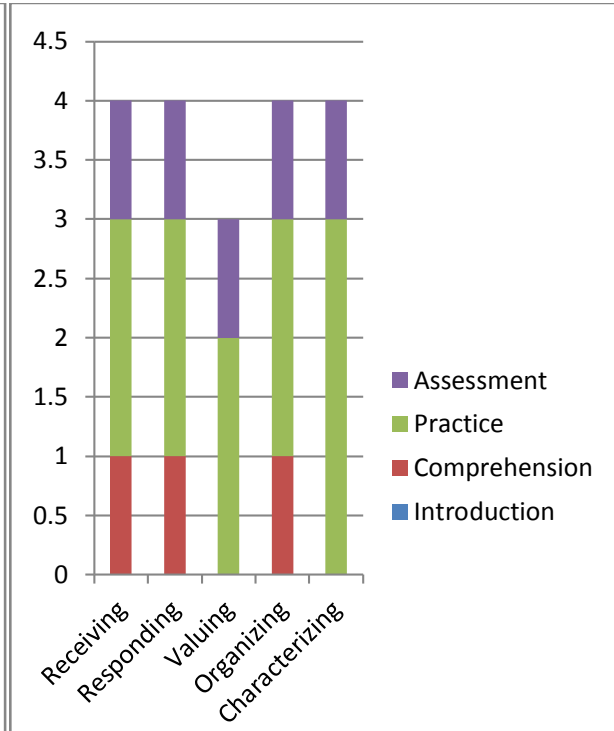

(b)

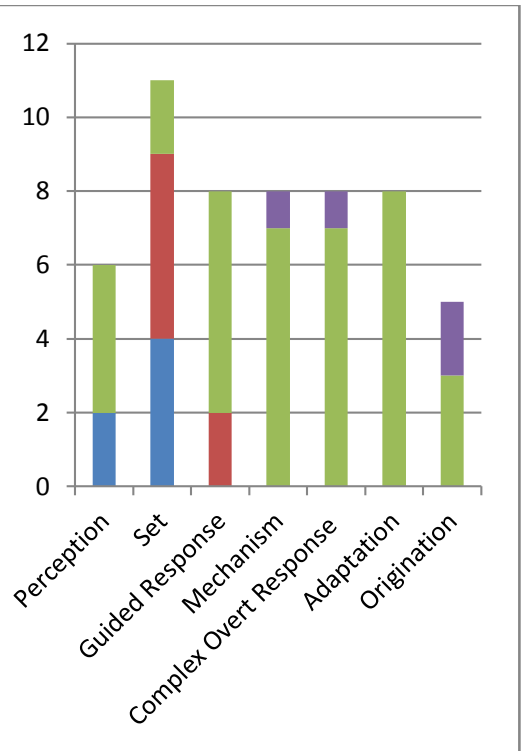

(c)

Figure 2. The proportion of Course type in each Learning Domain. (a) Cognitive Domain, (b) Affective Domain, (c) Psychomotor Domain 
TABLE 1.

THE REVISED BLOOM'S TAXONOMY IN COGNITIVE DOMAIN

\begin{tabular}{|c|c|}
\hline Category & Key Words \\
\hline $\begin{array}{l}\text { Knowlwdge change to Remembering: Recall previous learned } \\
\text { information. }\end{array}$ & $\begin{array}{l}\text { defines, describes, identifies, knows, labels, lists, matches, names, } \\
\text { outlines, recalls, recognizes, reproduces, selects, states. }\end{array}$ \\
\hline $\begin{array}{l}\text { Understanding: Comprehending the meaning, translation, } \\
\text { interpolation, and interpretation of instructions and problems. State a } \\
\text { problem in one's own words. }\end{array}$ & $\begin{array}{l}\text { Comprehends, converts, defends, distinguishes, estimates, explains, } \\
\text { extends, generalizes, gives an example, infers, interprets, paraphrases, } \\
\text { predicts, rewrites, summarizes, and translates. }\end{array}$ \\
\hline $\begin{array}{l}\text { Applying: Use a concept in a new situation or unprompted use of an } \\
\text { abstraction. Applies what was learned in the classroom into novel } \\
\text { situations in the work place. }\end{array}$ & $\begin{array}{l}\text { Applies, changes, computes, constructs, demonstrates, discovers, } \\
\text { manipulates, modifies, operates, predicts, prepares, produces, relates, } \\
\text { shows, solves, and uses. }\end{array}$ \\
\hline $\begin{array}{l}\text { Analyzing: Separates material or concepts into component parts so } \\
\text { that its organizational structure may be understood. Distinguishes } \\
\text { between facts and inferences. }\end{array}$ & $\begin{array}{l}\text { Analyzes, breaks down, compares, contrasts, diagrams, deconstructs, } \\
\text { differentiates, discriminates, distinguishes, identifies, illustrates, } \\
\text { infers, outlines, relates, selects, and separates. }\end{array}$ \\
\hline Evaluating: Make judgments about the value of ideas or materials. & $\begin{array}{l}\text { Appraises, compares, concludes, contrasts, criticizes, critiques, } \\
\text { defends, describes, discriminates, evaluates, explains, interprets, } \\
\text { justifies, relates, summarizes, and supports. }\end{array}$ \\
\hline $\begin{array}{l}\text { Creating: Builds a structure or pattern from diverse elements. Put } \\
\text { parts together to form a whole, with emphasis on creating a new } \\
\text { meaning or structure. }\end{array}$ & $\begin{array}{l}\text { categorizes, combines, compiles, composes, creates, devises, designs, } \\
\text { explains, generates, modifies, organizes, plans, rearranges, } \\
\text { reconstructs, relates, reorganizes, revises, rewrites, summarizes, tells, } \\
\text { writes. }\end{array}$ \\
\hline
\end{tabular}

TABLE 2.

BLOOM'S TAXONOMY IN AFFECTIVE DOMAIN

\begin{tabular}{|c|c|}
\hline Category & Key Words \\
\hline $\begin{array}{l}\text { Receiving Phenomena: Awareness, willingness to hear, selected } \\
\text { attention. }\end{array}$ & $\begin{array}{l}\text { asks, chooses, describes, follows, gives, holds, identifies, locates, } \\
\text { names, points to, selects, sits, erects, replies, uses. }\end{array}$ \\
\hline $\begin{array}{l}\text { Responding to Phenomena: Active participation on the part of the } \\
\text { learners. Attends and reacts to a particular phenomenon. Learning } \\
\text { outcomes may emphasize compliance in responding, willingness to } \\
\text { respond, or satisfaction in responding (motivation). }\end{array}$ & $\begin{array}{l}\text { answers, assists, aids, complies, conforms, discusses, greets, helps, } \\
\text { labels, performs, practices, presents, reads, recites, reports, selects, } \\
\text { tells, writes. }\end{array}$ \\
\hline $\begin{array}{l}\text { Valuing: The worth or value a person attaches to a particular object, } \\
\text { phenomenon, or behavior. This ranges from simple acceptance to the } \\
\text { more complex state of commitment. Valuing is based on the } \\
\text { internalization of a set of specified values, while clues to these values } \\
\text { are expressed in the learner's overt behavior and are often identifiable. }\end{array}$ & $\begin{array}{l}\text { completes, demonstrates, differentiates, explains, follows, forms, } \\
\text { initiates, invites, joins, justifies, proposes, reads, reports, selects, } \\
\text { shares, studies, works. }\end{array}$ \\
\hline $\begin{array}{l}\text { Organization: Organizes values into priorities by contrasting different } \\
\text { values, resolving conflicts between them, and creating a unique value } \\
\text { system. The emphasis is on comparing, relating, and synthesizing } \\
\text { values. }\end{array}$ & $\begin{array}{l}\text { Adheres, alters, arranges, combines, compares, completes, defends, } \\
\text { explains, formulates, generalizes, identifies, integrates, modifies, } \\
\text { orders, organizes, prepares, relates, synthesizes. }\end{array}$ \\
\hline $\begin{array}{l}\text { Internalizing values (characterization): Has a value system that } \\
\text { controls their behavior. The behavior is pervasive, consistent, } \\
\text { predictable, and most importantly, characteristic of the } \\
\text { learner. Instructional objectives are concerned with the student's } \\
\text { general patterns of adjustment (personal, social, emotional). }\end{array}$ & $\begin{array}{l}\text { Acts, discriminates, displays, influences, listens, modifies, performs, } \\
\text { practices, proposes, qualifies, questions, revises, serves, solves, } \\
\text { verifies. }\end{array}$ \\
\hline
\end{tabular}

TABLE 3.

BLOOM'S TAXONOMY IN PSYCHOMOTOR DOMAIN

\begin{tabular}{|c|c|}
\hline Category & $\begin{array}{c}\text { Key Words } \\
\end{array}$ \\
\hline $\begin{array}{l}\text { Percaption (awareness): The ability to use sensory cues to guide } \\
\text { motor activity. This ranges from sensory stimulation, through cue } \\
\text { selection, to translation. }\end{array}$ & $\begin{array}{l}\text { Chooses, describes, detects, differentiates, distinguishes, identifies, } \\
\text { isolates, relates, selects. }\end{array}$ \\
\hline $\begin{array}{l}\text { Set: Readiness to act. It includes mental, physical, and emotional sets. } \\
\text { These three sets are dispositions that predetermine a person's response } \\
\text { to different situations (sometimes called mindsets). }\end{array}$ & $\begin{array}{l}\text { Begins, displays, explains, moves, proceeds, reacts, shows, states, and } \\
\text { volunteers. }\end{array}$ \\
\hline $\begin{array}{l}\text { Guided Response: The early stages in learning a complex skill that } \\
\text { includes imitation and trial and error. Adequacy of performance is } \\
\text { achieved by practicing. }\end{array}$ & copies, traces, follows, react, reproduce, responds \\
\hline $\begin{array}{l}\text { Mechanism (basic proficiency): This is the intermediate stage in } \\
\text { learning a complex skill. Learned responses have become habitual and } \\
\text { the movements can be performed with some confidence and } \\
\text { proficiency. }\end{array}$ & $\begin{array}{l}\text { Assembles, calibrates, constructs, dismantles, displays, fastens, fixes, } \\
\text { grinds, heats, manipulates, measures, mends, mixes, organizes, and } \\
\text { sketches. }\end{array}$ \\
\hline $\begin{array}{l}\text { Complex Overt Response (Expert): The skillful performance of } \\
\text { motor acts that involve complex movement patterns. Proficiency is } \\
\text { indicated by a quick, accurate, and highly coordinated performance, }\end{array}$ & $\begin{array}{l}\text { Assembles, builds, calibrates, constructs, dismantles, displays, fastens, } \\
\text { fixes, grinds, heats, manipulates, measures, mends, mixes, organizes, } \\
\text { and sketches. }\end{array}$ \\
\hline $\begin{array}{l}\text { requiring a minimum of energy. This category includes performing } \\
\text { without hesitation, and automatic performance. For example, players } \\
\text { are often utter sounds of satisfaction or expletives as soon as they hit a } \\
\text { tennis ball or throw a football, because they can tell by the feel of the } \\
\text { act what the result will produce. }\end{array}$ & $\begin{array}{l}\text { NOTE: The Key Words are the same as Mechanism, but will have } \\
\text { adverbs or adjectives that indicate that the performance is quicker, } \\
\text { better, more accurate, etc. }\end{array}$ \\
\hline $\begin{array}{l}\text { Adaptation: Skills are well developed and the individual can modify } \\
\text { movement patterns to fit special requirements. }\end{array}$ & Adapts, alters, changes, rearranges, reorganizes, revises, and varies. \\
\hline $\begin{array}{l}\text { Origination: Creating new movement patterns to fit a particular } \\
\text { situation or specific problem. Learning outcomes emphasize creativity } \\
\text { based upon highly developed skills. }\end{array}$ & $\begin{array}{l}\text { Arranges, builds, combines, composes, constructs, creates, designs, } \\
\text { initiate, makes, originates. }\end{array}$ \\
\hline
\end{tabular}


TABLE 4.

KNOWLEDGE AND SKILL LEVEL ACCORDING TO STUDENT'S LEVEL OF EDUCATION

\begin{tabular}{|c|c|c|c|c|c|}
\hline No & Subject/ Course & Elementary School & Middle School & High School & Higher Education \\
\hline 1 & Teamwork & 1 & 2 & 2 & 3 \\
\hline 2 & Introduction to Robotics & 1 & 2 & 3 & 3 \\
\hline 3 & Mechanical Parts & 1 & 2 & 3 & 3 \\
\hline 4 & Electronics Parts & 1 & 1 & 2 & 3 \\
\hline 5 & Microcontroler Technology & 1 & 1 & 2 & 3 \\
\hline 6 & Software and Firmware & 1 & 1 & 2 & 3 \\
\hline 7 & Sensor & 1 & 2 & 2 & 3 \\
\hline 8 & Actuator & 1 & 2 & 2 & 3 \\
\hline 9 & Measurement & 1 & 2 & 3 & 3 \\
\hline 10 & Design & 1 & 2 & 3 & 3 \\
\hline 11 & Programming and Logics & 1 & 2 & 2 & 3 \\
\hline 12 & Control & 1 & 1 & 2 & 3 \\
\hline 13 & Robotics Workshop & 1 & 2 & 2 & 3 \\
\hline 14 & Robotics Competition & 1 & 2 & 3 & 3 \\
\hline
\end{tabular}

TABLE 5 .

CURRICULUM MATRIXFOCUSED IN COGNITIVE DOMAIN LEARNING OUTCOMES

Learning Outcomes

Subjects / Courses

ABET

Engineering

Criteria

Cognitive Domain (Revised Bloom's Taxonomy)

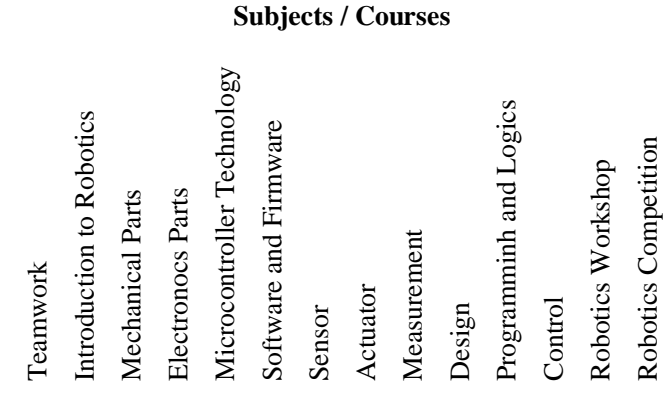

\begin{tabular}{|c|c|c|c|c|c|c|c|c|c|c|c|c|c|c|c|}
\hline \multirow{2}{*}{$\begin{array}{l}\text { Engineering } \\
\text { Knowledge }\end{array}$} & $\begin{array}{l}\text { Knowledge/ } \\
\text { Remembering }\end{array}$ & $\begin{array}{l}\text { Students remember and able to mention } \\
\text { robot components and their functions. }\end{array}$ & I & I & I & I & I & I & I & & & & I & & \\
\hline & Understanding & $\begin{array}{l}\text { robot components and able to descibe them } \\
\text { with their own sentence. }\end{array}$ & $\mathrm{C}$ & $\mathrm{C}$ & $\mathrm{C}$ & $\mathrm{C}$ & $\mathrm{C}$ & $\mathrm{C}$ & $\mathrm{C}$ & & I & & $\mathrm{C}$ & & \\
\hline \multirow{2}{*}{$\begin{array}{c}\text { An ability to } \\
\text { apply knowledge } \\
\text { of engineering }\end{array}$} & Applying & $\begin{array}{l}\text { Students able to use the robot components } \\
\text { and combine them in to determined design. }\end{array}$ & A & $\mathrm{P}$ & $\mathrm{C}$ & $\mathrm{C}$ & $\mathrm{C}$ & $\mathrm{P}$ & $\mathrm{P}$ & I & $\mathrm{C}$ & & $\mathrm{C}$ & $\mathrm{P}$ & $\mathrm{P}$ \\
\hline & Analyzing & $\begin{array}{l}\text { Students able to understand the concept of } \\
\text { the robots, its components and structure. }\end{array}$ & & $\mathrm{P}$ & $\mathrm{C}$ & $\mathrm{C}$ & $\mathrm{P}$ & $\mathrm{P}$ & $\mathrm{P}$ & $\mathrm{C}$ & $\mathrm{P}$ & $\mathrm{C}$ & $\mathrm{P}$ & $\mathrm{P}$ & $\mathrm{P}$ \\
\hline $\begin{array}{c}\text { An ability to } \\
\text { conduct standard } \\
\text { tests, analyze, } \\
\text { and interpret } \\
\text { experiments }\end{array}$ & Evaluating & $\begin{array}{l}\text { Students able to make a judgments about a } \\
\text { robot design or idea for the given problem. }\end{array}$ & & $\mathrm{P}$ & $\mathrm{P}$ & $\mathrm{P}$ & A & A & A & $\mathrm{P}$ & A & $\mathrm{P}$ & $\mathrm{P}$ & $\mathrm{P}$ & $\mathrm{P}$ \\
\hline $\begin{array}{l}\text { A commitment to } \\
\text { quality, } \\
\text { timeliness, and } \\
\text { continuous } \\
\text { improvement }\end{array}$ & Creating & $\begin{array}{l}\text { Students able to make a new robotics } \\
\text { structure or design using the available } \\
\text { robotics component. } \\
\text { Students able to make a new robot } \\
\text { component based on their designed } \\
\text { structure to improve the performance using } \\
\text { the previously available components. }\end{array}$ & & A & $\mathrm{P}$ & $\mathrm{P}$ & $\mathrm{P}$ & $\mathrm{P}$ & $\mathrm{P}$ & $\mathrm{P}$ & A & $\mathrm{P}$ & $\mathrm{P}$ & A & A \\
\hline
\end{tabular}


TABLE 6.

CURRICULUM MATRIX FOCUSED IN AFFECTIVE DOMAIN LEARNING OUTCOMES

Learning Outcomes

Subjects / Courses

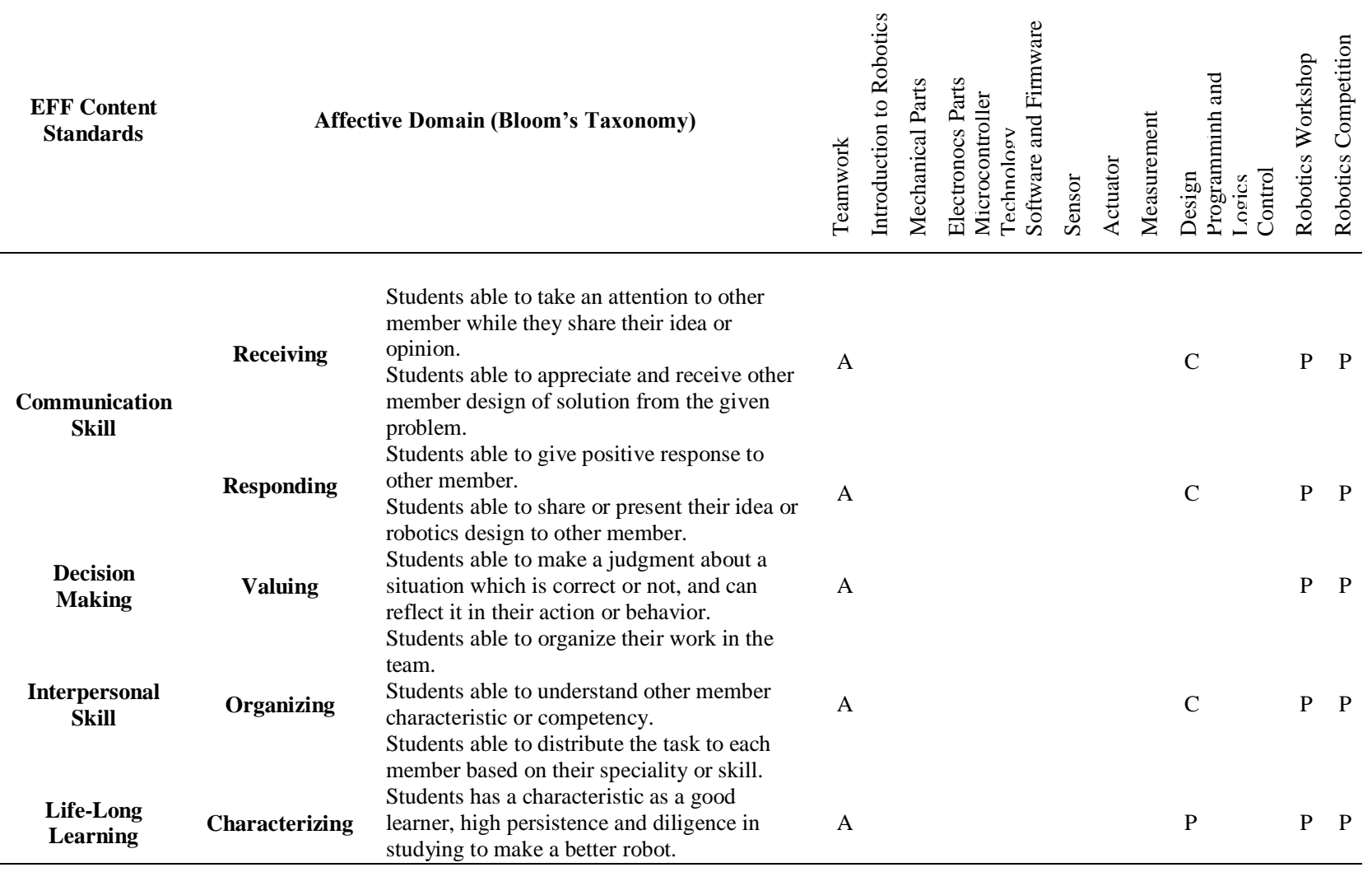

TABLE 7.

CURRICULUM MATRIX FOCUSED IN PSYCHOMOTORIC DOMAIN LEARNING OUTCOMES

Learning Outcomes

Psychomotoric Domain (Bloom's Taxonomy)
Subjects / Courses

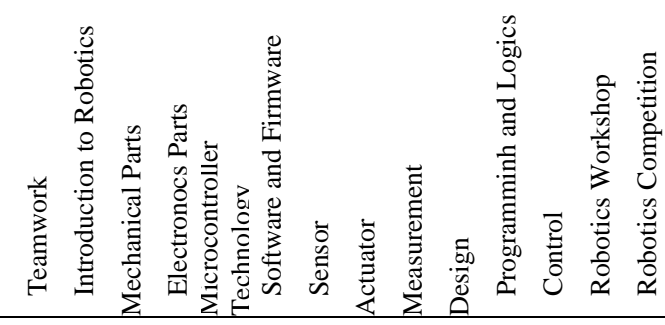

Perception Students able to use their sensory cues to make observation

(Awareness) $\quad$ Students able to differenciate robot parts based on the visual inspection.

Set Students able to response the environment and ready to

( Readiness to act) take an actions regarding to the situation/ or given order.

Students can perform action following the instruction/

Guided Response example given by the intructor in manipulating parts or using tools.

Mechanism Students obtain a skill to handle and manipulate robotic

(Basic proficiency) parts, using robot development tools.

$\mathrm{P} \quad \mathrm{P}$

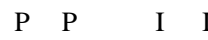

Students obtain an expetise in handling and manipulating

Complex Overt Response (Expert) robotics parts, using development tools and other physical parts.

Proficiency is indicated by a quick, accurate, and highly coordinated performance, requiring a minimum of energy. Students able to adapt with a new robotics parts without to

Adaptation be demostrated or guided by instructors Students can rearrange in handling or manipulating robotics part to fits special requirements.

Students able to develope a new pattern or movement in

Origination handling or manipulating robot or its parts based on their own creativity. 


\section{REFERENCES}

[1] M. J. Mataric, "Robotics Education for All Ages", Proceedings, AAAI Spring Symposium on Accessible, Hands-on AI and Robotics Education, Palo Alto, CA, Spring 2004.

[2] J. Johnson, "Children, robotics, and education", Artificial Life and Robotics, Vol. 7, No. 1-2, pp. 16-2.

[3] D. Alimisis, A. Karatrantou, and N. Tachos, "Technical school students design and develop robotic gear-based constructions for the transmission of motion", Digital Tools for Lifelong Learning, Proceeding, Warsaw: Druk Sfera, pp. 76-86, Euro logo 2005.

[4] O. Miglino, H.H. Lund, and M. Cardaci, Robotics as an Educational Tool. Journal of Interactive Learning Research, Vol.10, No. 1, pp. 25-48, 1999.

[5] J.K. Archibald, and R.W. Beard, "Competitive Robot Soccer: a Design Experience for Undergraduate Students". Frontiers in Education Conference. Boston, MA, 2002.

[6] D.J. Ahlgren, "An International View of Robotics as an Educational Medium". International Conference on Engineering Education. Manchester, UK, 2002

[7] A. Dimitris, "Educational robotics: Open questions and new challenges," Themes in Science \& Technology Education, Vol. 6, No. 1, pp. 63-71, 2013.

[8] R. Wicklein, P. C. Smith, Jr., and S. J. Kim, "Essential Concepts of Engineering Design Curriculum in Secondary Technology Education," Journal of Technology Education, Vol. 20 No. 2, Spring 2009.

[9] R.T. Wright and D.P. Lauda, "Technology education - A position statement", The Technology Teacher, Vol. 52, No. 4, pp. 3-5, 1993.

[10] B.S. Bloom, “Taxonomy of Educational Objectives, Handbook I: The Cognitive Domain,” New York: David McKay Co Inc., 1956

[11] E. Murphy, "Developing and writing educational objectives", pp. 19-22, 1997

[12] M. Forehand, "Bloom's Taxonomy from Emerging Perspectives on Learning," Teaching and Technology, 12 Jan 2008

[13] A.K . Junoh, W. W.Z.A. Muhammad, N. Ghazali, W. W.N. Jaafar, S. Saad, and S.N.A.Aluwi, "Allocation Marks Model for Examination Based on Bloom's Taxonomy," International Conference on Modeling, Simulation and Control, IPCSIT , Vol.10, IACSIT Press, Singapore, 2011
[14] L.W. Anderson, D. R. Krathwohl, P.W. Airasian, K.A Cruikshank, R.E. Mayer, P.R. Pintrich, J. Raths, AND M. C. Wittrock,"A Taxonomy for Learning, Teaching, and Assessing: A revision of Bloom's Taxonomy of Educational Objectives," New York: Pearson, Allyn \& Bacon, 2000

[15] D.R. Krathwohl, B.S. Bloom, and B.B. Masia," Taxonomy of Educational Objectives, the Classification of Educational Goals. Handbook II: Affective Domain,” New York: David McKay Co., Inc., 1973.

[16] E.J. Simpson "The Classification of Educational Objectives in the Psychomotor Domain," Washington, DC: Gryphon House, 1972.

[17] S. Sondra, "Equipped for the Future Content Standards: What Adults Need to Know and Be Able to Do in the 21st Century," National Institute for Literacy, January, 2000.

[18] L.W. Anderson, D.R. Krathwohl, P.W. Airasian, K.A Cruikshank, R.E. Mayer, P.R. Pintrich, J. Raths, and M.C Wittrock, "A Taxonomy for learning, teaching, and assessing: A revision of Bloom's Taxonomy of Educational Objectives," New York: Longman, 2001.

[19] ___Criteria For Accrediting Engineering Programs: 2012-2013 Criteria for Accrediting Engineering Programs," Engineering Accreditation Commission (ABET), 2011.

[20] R. Felder, R. Brent, "Designing and Teaching Courses to Satisfy the ABET Engineering Criteria'" Journal of Engineering Education, Vol. 92, No.1, pp. 7-25, 2003.

[21] R.F. Mager, "Preparing Instructional Objectives: A Critical Tool in the Development of Effective Instruction. 3rd ed," Atlanta: Center for Effective Performance, 1997.

[22] N.E. Gronlund, "How to Write and Use Instructional Objectives 6th ed.," Englewood Cliffs, NJ: Prentice-Hall, 1999.

[23] K.M. Edens, "Preparing problem solvers for the 21st century through problem-based learning", College Teaching. Vol. 48, No. 2, pp. $55-60,2000$.

[24] D.R. Woods, The future of engineering education.3. Developing critical skills," Chemical Engineering Education. Vol. 34, No. 2, pp. 108-117, 2000

[25] D.R. Woods, "Developing problem-solving skills: The McMaster problem solving program". Journal of Engineering Education. Vol. 86, No. 2, pp. 75-91, 1997.

[26] D.W. Johnson, R.T. Johnson, and K.A. Smith., "Active Learning: Cooperation in the College Classroom. 2nd ed.", Edina. MN Interaction Book Co., 1998. 